\title{
DOES ETHICS NEED RELIGION? EVALUATING THE IMPORTANCE OF RELIGIOSITY IN CONSUMER ETHICS
}

\begin{abstract}
Purpose - The purpose of this study is to investigate the importance of religiosity in consumer ethics. This objective will be achieved by (1) investigating the impact of intrinsic and extrinsic religiosity on consumer ethics, and (2) segmenting consumers' religiosity and explore differences between each segment.

Design/methodology/approach - The surveys were distributed to undergraduate students, their friends, and members of their immediate families, through a large public university in Australia. Of 700 paper questionnaires, participants returned 651. Incomplete surveys with too many missing values were removed from the sample. Of these, 517 were usable, yielding a response rate of $74 \%$. Singles accounted for $53.9 \%$ of the sample, followed by married people (26.8\%). Of the respondents, $49.9 \%$ were men. The majority of respondents were between 18 and 24 years old (52\%), followed by 15-34 years (16.4\%). Finally, most respondents had an income level of less than $\$ 20,000$ (36.6\%) followed by $\$ 21,000-\$ 40,000$ (20.5\%) and $\$ 41,000-\$ 61,000$ (19.7\%). Overall, despite being dominated by younger consumers, the sample is relatively representative of the entire adult population of Australia.
\end{abstract}

Findings - The results show that both intrinsic and extrinsic religiosity had an impact consumers' ethical beliefs. Moreover, the results show significant differences between the two segments studied. The religious segment was more likely than the less-religious segment to reject various unethical beliefs, but no significant differences were found in the behavioural dimensions of recycling and doing good deeds.

Originality/ Value - This is one of the first few studies to explore the impact of religiosity on consumer ethics in Australia. The present study contributes to the consumer ethics literature by examining the role of religiosity in determining ethical beliefs. The results of this study have several implications for academic researchers, religious leaders and managers working in the area of consumer ethics.

Keywords: Consumer Ethics, Intrinsic Religiosity, Extrinsic Religiosity, Australia Paper type Research paper

\section{Introduction}

Despite an increase in the U.S., a recent report shows that the number of religiously unaffiliated people (i.e., atheists, agnostics) has been declining throughout the rest of the world (Pew Research 2015). Christians and Muslims will account for two-thirds of the global population after 2070, indicating that not all societies are likely to become more 
secular, and strongly suggesting that religion will continue to play an important role in human affairs worldwide (Pew Research 2015). Religion has played a vital role in human affairs since the dawn of civilization. Although the modern age has seen an increase in secularization in some parts of the world, it is certain that the role of religion will remain important in virtually all societies for the foreseeable future (Arli et al. 2016; Cornwell et al 2005). Huffman (1988) suggests that religiosity is a stronger determinant of people's values than any other predictor. Religion has always played an important role in the formation of beliefs, values, and social normative systems in society (Swinberghe et al. 2011). A number of authors have demonstrated the importance of religion in influencing ethical judgement (Arli and Tjiptono 2014; Vitell et al. 2003; Vitell et al. 2005). Nonetheless, with changes in global religiosity and an increase of secularism in various part of the world (Sanchez 2016), there is a need to constantly update and re-evaluate the influence of religion on ethical judgments in society. In addition, there is conflicting evidence on whether people who appear to have high level of religiosity are less likely to engage in unethical behaviours (Andaya 2010; Coopers et al. 2013; Rzu 2006). This begs the questions of why there are discrepancies between people’s faith and their subsequent behaviours. Moreover, relatively few studies in consumer ethics incorporate the religiosity construct (Albaum and Peterson 2006; Cornwell et al. 2005; Parwardhan et al. 2012). It has also been shown that attitudes toward various ethical beliefs in one context may be different in another context (e.g., country, culture, ethnicity) (Arli and Tjiptono 2014; Cornwell et al 2005; Swaidan et al. 2006).

Hence, the purpose of this study is to investigate the importance of consumers' religiosity on consumer ethics in Australia. This objective will be achieved through two approaches: (1) by investigating the impact of intrinsic and extrinsic religiosity on consumer ethics and (2) by segmenting consumers' religiosity and exploring differences between the 
segments. Segmentation is an effective ways to identify differences among groups, which will drive how we approach a solution (Dietrich et al. 2015). Therefore, the present study contributes to the consumer ethics literature by examining the role of religiosity in determining ethical beliefs. In addition, the results of this study will have several implications for academic researchers, religious leaders and managers working in the area of consumer ethics.

\section{Literature Review}

\subsection{Consumer ethics}

Consumer attitudes toward unethical practices have received considerable attentions in the last few decades (Cooper and Pullig 2013; Pekerti and Arli 2015; Shaw and Clarke 1999; Vitell 2003). Muncy and Vitell (1992) defined consumer ethics as "the moral principles and standards that guide behaviour of individuals or groups as they obtain, use and dispose of goods and services” (p. 298), and designed the most widely used construct of consumer ethics scales (CES). The scale examined consumers' ethical beliefs regarding questionable behaviour. The updated scale consisted of six dimensions, including: a) actively benefiting from illegal activities, such as giving misleading price information to a clerk for an unpriced item (ACTIVELY BENEFITING), b) passively benefiting activities, such as not saying anything when the waitress miscalculated the bill in your favour (PASSIVELY BENEFITING), c) actively benefiting from deceptive (or questionable, but legal) practices, such as returning merchandise to a store by claiming it was a gift when it was not (QUESTIONABLE BEHAVIOR), and d) no harm/no foul activities such as using computer software or games that you did not buy (NO HARM), e) recycling/environmental awareness, such as recycling materials like cans, bottles, newspapers etc. (RECYCLING), and f) doing the right thing/doing good, such as giving a larger than expected tip to a waiter or waitress. 
(DOING GOOD) (Muncy and Vitell, 2005). Most studies found that subjects believed that it was more ethical to benefit from a passive activity than from an active/illegal activity. In addition, consumers held the view that benefiting from a passive activity was more unethical than benefiting from questionable behaviour. Moreover, the perception of no harm/no foul involvement was generally acceptable and considered more ethical than the other three ethical beliefs (i.e., actively benefiting, passively benefiting and questionable behavior) (Vitell and Paolillo 2003; Arli and Tjiptono 2014).

Consumer ethical scales developed by Muncy and Vitell (2005) have been widely tested in various countries such as Australia (Chowdury and Fernando 2013; Pekerti and Arli 2015; Rawwas et al. 1996); Belgium (Van Kenhove et al. 2001); China (Zhao and Xu 2013); Egypt (Al-Khatib et al. 1995; Al-Khatib et al. 1997; Al-Khatib et. al. 2002; Rawwas 2001; Rawwas et al. 1994); France (Gentina et al. 2015); Hong Kong (Chan et al. 1998; Bateman et al. 2002); Japan (Erffmeyer et al. 1999); Northern Ireland (Rawwas et al. 1998); Lebanon (Rawwas, 2001; Rawwas et al. 1998); Saudi Arabia, Oman, and Kuwait (Al-Khatib et al. 2005); Singapore (Ang et al. 2001); Slovenia (Culiberg 2015); Thailand (Arli et al. 2015); Taiwan (Lu et al. 2015) and most frequently in the United States (Albers-Millers 1999; Bateman et al. 2002; Dodge et al. 1996; Flurry and Swimberghe 2016; Garner et al. 1999; Muncy and Vitell 1992; Muncy and Eastman 1998; Rallapalli et al. 1994; Rawwas and Singhapakdi 1998; Strutton et al. 1994; Vitell and Muncy 1992; Vitell et al. 2001). However, despite the large number of studies devoted to consumer ethics, there are still relatively few have investigated the role of religiosity in consumer ethics.

\subsection{Religion and Consumer Ethics}

Hunt and Vitell (1993) in their "general theory of marketing ethics" consider religion as an important factor that influences one’s ethical judgments. The religious beliefs of an 
individual will influence his or her ethical decision-making process (Hunt and Vitell 1986, 1993). McDaniel and Burnett (1990) defined religiosity as a belief in God and a commitment to follow rules and principles believed to have been set by God. Similarly, Johnson et al. (2001) defined religion as a belief, as well as a behavioral and attitudinal commitment to the teaching of religion. Allport and Ross (1967) defined religiosity as the extent to which a person lives out his or her religious beliefs, and they also distinguished between intrinsic religiosity and extrinsic religiosity. "The extrinsically motivated person uses his religion whereas the intrinsically motivated lives his religion” (Allport and Ross 1967, p. 434). Intrinsic religiosity is "indicative of having religious commitment and involvement for more inherent, spiritual objectives” (Vitell et al. 2009, p. 158). Intrinsically religious individuals tend to be more ethical in their beliefs than less religious individuals (Arli and Tjiptono 2014; Vitell and Paolillo 2003; Vitell et al. 2015). In contrast to intrinsic religiosity, Allport (1959, p. 264-5) defines extrinsic religiosity as a context where "Religion is not the master-motive in the life. It plays an instrumental role only. It serves and rationalizes assorted forms of selfinterest. In such a life, the full creed and teaching of religion are not adopted. The person does not serve his religion; it is sub-ordinated to serve him. The master-motive is always self-interest.” Hence, an individual with a strong extrinsic religiosity is influenced by social determinants, and tends to participate in religious activities to meet personal needs (e.g., source of comfort and peace) or social goals (e.g., social support). Vitell (2010, p. 164) noted that "no study seems to have examined the impact of religiosity might have on actual behaviour in situations involving ethical issues.” A few studies have examined this issue, but the results remain inconclusive, especially with respect to the influence of extrinsic religiosity on consumer ethics.

In regards to intrinsic religiosity, and specifically regarding its impact on consumer ethics, the research has produced results that are largely consistent. Most studies found that 
intrinsic religiosity had a negative effect on most consumer ethics’ measures (e.g., Arli and Tjiptono 2014; Flurry and Swinberghe 2015; Patwardhan et al. 2012; Vitell et al. 2005; Vitell et al. 2006; Vitell et al. 2007). One study found that intrinsic religiosity had no effect on consumer ethics among German subjects, but still had a negative effect on their sample from Turkey (Schneider et al. 2011). Finally, spirituality had a negative effect on consumer ethics (Vitell et al. 2015). Only one study ( Vitell and Paollio 2003) found that religiosity had no effect on consumer ethics.

In regards to extrinsic religiosity, the research has produced mixed results. Some studies found that extrinsic religiosity had no effect on consumer ethics (e.g., Flurry and Swimberghe 2015; Vitell et al. 2005; Vitell et al. 2007). In contrast, other studies found that extrinsic religiosity had a positive effect on consumer ethics' measures (e.g., Patwardhan et al. 2012; Arli and Tjiptono 2014). Finally, no significant differences were found between Islam and other religions with respect to the consumers' ethical beliefs of their followers (Lu and $\mathrm{Lu}$ 2010). More research is needed to investigate the impact of religiosity, especially the impact of extrinsic religiosity, on consumer ethical beliefs. Table 1 summarizes all studies using religiosity-related scales and consumer ethics scales developed by Muncy and Vitell (2005) (only religiosity-related scale items are displayed).

Insert Table 1 about Here

\section{Hypothesis Development}

The study tests the influence of intrinsic and extrinsic religiosity on consumer ethical beliefs (i.e., Actively Benefiting, Passively Benefiting, Questionable Behavior, No Harm, Recycling and Doing Good). Subsequently, three main hypotheses will be proposed (two from the conceptual framework, and one from the segmentation study). The conceptual framework is summarized in Figure 1. 


\section{Insert Figure 1 about Here}

\subsection{The Impact of Intrinsic Religiosity on Consumer Ethics}

A number of studies have found that intrinsic religiosity significantly influences consumers' ethical judgement (Arli and Tjiptono 2014; Patwardhan et al. 2012; Vitell et al. 2005; Vitell et al. 2006; Vitell et al. 2007). Consumers with higher intrinsic religiosity tended to have greater concern for ethical standards (Vitell et al. 2003). Similarly, Donahue (1985) found that intrinsic religiosity is more strongly correlated with religious commitment than is extrinsic religiosity. Based on the previous discussion, it is reasonable to believe that consumers with high intrinsic religiosity would place a high degree of importance on religion, thus making these individuals more ethically aware and more sensitive toward various unethical behaviours. Hence, the study proposed:

H1: Intrinsic Religiosity will negatively influence consumers' ethical beliefs: (a) Actively Benefiting; (b) Passively Benefiting; (c) Questionable Behaviour; (d) No-Harm and positively influence (e) Recycling and (f) Doing Good.

\subsection{The Impact of Extrinsic Religiosity on Consumer Ethics}

Several studies show that extrinsic religiosity does not measure individuals’ religiosity but rather reflects their attitude toward religion as a source of comfort and social support (Donahue 1985; Vitel 2010). Arli and Tjiptono (2014) found that extrinsic religiosity positively influenced their ethical beliefs. Extrinsically-religious consumers may not be committed to religion beyond the appearance of their actions. Consequently, these consumers may not have strong ethical beliefs (Patwardhan et al. 2012). Consumers with high extrinsic religiosity are more likely to accept these unethical behaviours and less likely to accept ethical behaviour. Thus, this study hypothesizes:

H2: Extrinsic Religiosity will positively influence consumers' ethical beliefs: (a) Actively Benefiting; (b) Passively Benefiting; (c) Questionable Behaviour; (d) No-Harm and negatively influence (e) Recycling and (f) Doing Good. 


\subsection{Segmentation}

Kennedy and Lawton (1998) found differences in their ethical behaviour between students from a religious institution versus a non-affiliated institution. Students from the religious institution were more likely to behave ethically. Studies show that an individual may exhibit a combination of intrinsic and extrinsic religiosity instead of either or (Allport and Ross 1967; Vitell et al. 2005; Arli and Tjiptono 2014). Hence, a segmentation analysis is needed to identify segment of religious and less religious consumers. Consumers with stronger religious belief are likely to be more ethical in their beliefs than the less religious consumers (Clark and Dawson 1996; McNichols and Zimmerer 1985). This leads to:

H3: There is a significant difference between 'Less-religious' and 'Religious' Consumers in ethical beliefs: (a) Actively Benefiting; (b) Passively Benefiting; (c) Questionable Behaviour; (d) No-Harm and negatively influence (e) Recycling and (f) Doing Good.

\section{Methodology}

\subsection{Survey and Procedures}

The surveys were distributed to undergraduate students, their friends, and members of their immediate families, through a large public university in Australia. Students received credit points for participating in this study. Australia had a population of around 24 million as of 2016 (Australian Bureau of Statistics, 2016). The median age of Australians is 36.9, with around $41.8 \%$ of the population between $25-54$ years of age. The nation's GDP per capita is around US\$ 67,458 (2013) compared to US\$53,958 in the US (World Bank, 2013). Finally, 61.1\% of Australian declared a variety of Christian denominations while 22.3\% Australian stated “no religion”. The remaining population includes Buddhist (2.5\%), Muslim (2.2\%), Hindus (1.3\%) and Jews (0.5\%) (Australian Bureau of Statistic 2011).

Of 700 paper questionnaires, participants returned 651. Incomplete surveys with too many missing values were removed from the sample. Of these, 517 were usable, yielding a 
response rate of $74 \%$. Singles accounted for $53.9 \%$ of the sample, followed by married people (26.8\%). Of the respondents, $49.9 \%$ were men. The majority of respondents were between 18 and 24 years old (52\%), followed by 15-34 years (16.4\%) and 45-54 years (15.9\%). Finally, most respondents had an income level of less than $\$ 20,000$ (36.6\%) followed by $\$ 21,000-\$ 40,000$ (20.5\%) and \$41,000-\$61,000 (19.7\%). Overall, despite being dominated by younger consumers, the sample is relatively representative of the entire adult population of Australia. Table 2 summarizes the demographic profile of the respondents. Insert Table 2 about Here

\subsection{Measures and Reliability}

In regards to religiosity, the study employed Allport and Ross’s (1967) widely-used religiosity scale items to measure the intrinsic and extrinsic religiosity of the respondents. The scale examines respondents' religiosity using a 5-point Likert-type scale ranging from 1 $=$ strongly disagree to $5=$ strongly agree. Hence, the higher the mean value, the higher the subject’s intrinsic/ extrinsic religiosity. Moreover, to assess consumer ethics, we used Muncy and Vitell's consumer ethics scale (CES) (Vitell and Muncy, 2005). The scale examines consumer ethical beliefs regarding specific ethical behaviors, using a 5-point Likert-type scale ranging from $1=$ strongly believed it is acceptable to $5=$ strongly believed it is unacceptable. The measure consists of six dimensions: (a) Active Benefiting; (b) Passively Benefiting; (c) Questionable Behavior; (d) No Harm; (e) Recycle; and (f) Doing Good. Hence, the higher the mean values, the more consumers perceive these behaviors unacceptable. We asked demographic questions at the end of the survey. Table 3 summarizes the scale items used in this study

Exploratory factor analysis showed that each item loaded highly on the corresponding factor, with factor loadings ranging from 0.61 to a maximum of 0.92 . Before testing 
hypotheses, the study assessed the convergent and discriminant validity of all measures. Using structural equation modelling (AMOS), a confirmatory factor analysis was conducted (CFA) on the measures. The fit of the model was good $\left(x^{2}(\mathrm{df})=785.579(428)\right.$; CFI = .97; $\mathrm{TLI}=0.96 ; \mathrm{NNFI}=.93 ; \mathrm{RMSEA}=.04 ; \mathrm{SRMR}=.03)$. The fit of the model was well above the recommended values (Joreskor and Sorbom, 1993; Steiger, 1990).

The study calculated Cronbach’s alpha for each key variable to test for internal consistency reliability. Values below the threshold of .60 indicate unsatisfactory internal consistency (Malhotra and Birks, 2007). Tests for convergent and discriminant validity and composite reliability were conducted. The study assessed convergent validity by determining whether factor loadings were greater than .50 and statistically significant $(\mathrm{p} \leq .05)$. The minimum factor loading in this study was 0.59 (Bagozzi and Yi 2012). Confidence intervals around the correlation estimates between any two constructs were all significantly different from one (Gerbing and Anderson 1988). To assess discriminant validity among the constructs, we compared the average variance extracted (AVE) values for each construct with the squared correlation estimates of paired measured constructs in the model (Fornell Larcker 1981). The AVE ranged from 0.51 to a maximum of 0.79 . The study calculated composite reliability values (CR) and compared them to a threshold benchmark of .60 (Bagozzi Yi, 1988). The minimum CR of this study ranged from 0.81 to 0.92 . The variance extracted was tested and the AVE for each factor was higher than the square of the correlation coefficient with each of the other factors (see Table 4). Thus, the test confirms the measurement model discriminant validity (Fornell and Larcker 1981). Common method variance was tested by comparing both measurement models to one-factor models. The onefactor models showed significantly inferior statistics in comparison to our model.

Having established the unidimensionality and reliability of the models, in the next step we estimated the hypothesized relationships between the constructs of this study. 
Overall, the findings presented in Table 5 suggested that the hypothesized structure model fit the data well, $x^{2}(442 \mathrm{df})=936.769, p=0.00 ; \mathrm{NFI}=0.92 ; \mathrm{TLI}=0.95 ; \mathrm{CFI}=0.96$; $\mathrm{IFI}=0.96$; RMSEA $=0.047$. Tables 3, 4 and 5 summarize the scale items correlation, the validity and reliability results, and the structural equation model results.

\section{Insert Table 3, 4 and 5 about Here}

\subsection{Segmentation}

Donovan et al. (1999) suggest three key steps in segmenting population: (a) identifying homogenous segments within a larger heterogeneous population, (b) evaluating and selecting one or multiple segment(s), and (3) developing a program suited to the unique needs and characteristics of the target segment(s). A Two-Step cluster analysis was conducted, using baseline consumer ethics psychographic measures. A silhouette of more than 0.0 is needed for the within-cluster distance and the between-cluster distance to be valid (Norusis 1994). The analysis produced a sample $(\mathrm{N}=517)$, with a silhouette measure of cohesion and separation of 0.7 , which can be considered “Good.” Moreover, a cross-validating method of the identified segment was conducted by dividing the total sample $(n=517)$ in half and repeating the identical analysis on each half of the sample (Punj and Steward 1983). Based on the results from the cluster analysis presented in Table 6, consumers were segmented into two distinct clusters/segments. The segments were labelled Less-religious Consumers $\left(\mathrm{M}_{\text {INTRINSIC }}=1.51 ; \mathrm{M}_{\text {EXTRINSIC }}=1.28\right)$ and Religious Consumers $\left(\mathrm{M}_{\text {INTRINSIC }}=3.26\right.$; $M_{\text {EXTRINSIC }}=2.85$ ). The variables' individual predictor importance score (ranging from 0 for least important to 1 for most important) were assessed. The "Intrinsic Religiosity" construct was the most distinguishing factor, with a predictor importance score of (1.0), followed by “Extrinsic Religiosity” (0.89). There were significant $(p<0.05)$ inter-cluster differences on 
both of the construct variables. These results provided evidence that our clusters are reliable. Each segment will be discussed in details in the next section.

\section{Insert Table 6 about Here}

\section{Results}

\subsection{Conceptual Model}

The results show intrinsic religiosity has a positive influence on: Actively Benefiting ( $\beta=$ 6.749, $p<0.00$ ); Passively Benefitting $(\beta=8.469, p<0.00)$; Questionable Behaviour $(\beta=$ 8.143, $p<0.00)$ and No-harm $(\beta=6.477, p<0.00)$. The higher the respondents' religiosity, the more likely they are to consider those behaviours unacceptable. Hence, H1a, H1b, H1c and H1d are supported. Moreover, intrinsic religiosity negatively influenced doing good $(\beta=$ $-2.142, p<0.05)$. This shows that high intrinsic religious consumers are more likely to consider doing good acceptable. Thus, H1f is supported. However, intrinsic religiosity did not influence Recycling. Hence, H1e is not supported.

In regards to extrinsic religiosity, the results reveal that extrinsic religiosity negatively influenced: Actively Benefiting ( $\beta=-6.542, p<0.00$ ); Passively Benefiting $(\beta=-8.107, p<$ 0.00); Questionable Behavior $(\beta=-7.788, p<0.00)$ and No-Harm $(\beta=-6.178, p<0.00)$. Therefore, H2a, H2b, H2c, and H2d are supported. Moreover, extrinsic religiosity positively influenced doing good, which means that the higher their extrinsic religiosity the more likely respondents will perceive doing good as unacceptable $(\beta=2.139, p<0.05)$. Hence, H2f is supported. Finally, extrinsic religiosity did not influence Recycling. Thus H2e is not supported.

\subsection{Segmentation}


The segmentation procedures produce two segments. The first segment is called The Lessreligious Consumers segment. This segment has $45.3 \%$ of the total respondents. These consumers had significantly lower mean scores on their intrinsic religiosity $(M=1.48)$ and extrinsic religiosity $(M=1.58)$ compared to religious consumers' segment. The second segment is called The Religious Consumers segment. This segment has $54.7 \%$ of the total respondents. These consumers had higher intrinsic religiosity $(\mathrm{M}=3.36)$ and higher extrinsic religiosity $(M=3.13)$ than the less-religious consumers segment. The segmentation results show that consumers with high intrinsic religiosity tend to have higher extrinsic religiosity than the less-religious segment. The independent t-test shows significant differences between The Less-religious Consumers segment versus The Religious Consumers segment on their ethical beliefs: Actively Benefiting $\left(\mathrm{M}_{\text {Less-religious }}=3.88, \mathrm{M}_{\text {Religious }}=4.06, p<0.05\right)$; Passively Benefiting $\left(\mathrm{M}_{\text {Less-religious }}=3.14, \mathrm{M}_{\text {Religious }}=3.66, p<0.000\right)$; Questionable Behavior $\left(\mathrm{M}_{\text {Less- }}\right.$ religious $\left.=3.04, \mathrm{M}_{\text {Religious }}=3.54 p<0.00\right)$; No-harm $\left(\mathrm{M}_{\text {Less-religious }}=2.58 ; \mathrm{M}_{\text {Religious }}=3.07, p<\right.$ 0.00). Hence, H3a, H3b, H3c and H3d are supported. Religious consumers are more likely to believe that those unethical behaviours are unacceptable compared to the less-religious segment. However, no significant differences were found on recycling and doing good deeds behaviour. Therefore, H3e and H3f are not supported. In general, there results clearly indicated that religious consumers tend to be more ethical than their less-religious counterparts except on their recycling behaviour and doing good deeds (see Table 6).

\section{Discussion and Implications}

The results of this study make contributions in several ways. First, this study confirms the consistently of consumer ethical beliefs scales (i.e., Muncy and Vitell 2005) across different contexts. This study also supported that many people believe it is more ethical to benefit from a passive activity than from an active/illegal activity. In addition, consumers in 
Australia noted that benefiting from a passive activity was more unethical than benefiting from questionable behaviour. Future studies exploring consumer ethics/ ethical beliefs should employ these scales (i.e., Muncy and Vitell 2005) in order to accurately measure consumers' level of ethicality. Second, the results indicated that consumers' religiosity plays an important role in influencing consumer ethical beliefs. Religion still matters. Consumers with high intrinsic religiosity are more likely to behave ethically, compared to consumers with high extrinsic religiosity. However, consumers with intrinsic and extrinsic religiosity did not differ on recycling. This result is consistent with other studies (i.e., Arli and Tjiptono 2014) suggesting that religious consumers are not more likely to support the environment through activities such as recycling or paying more for green products, compared to the lessreligious consumers. The results show that recycling and other environmental behaviour is an important issue to both religious and less-religious consumers.

Moreover, extrinsic religiosity negatively influences consumer ethical belief. This is in contrast with Vitell et al (2005) and Vitell et al. (2007), but in support of research by Arli and Tjiptono (2014) and Schneider et al. (2011), and partly supporting Patwardhan et al. (2012). The results suggest that the impact of extrinsic religiosity on consumers' ethical beliefs may change over time. Hence, in a different context, extrinsic religiosity may have different effects on consumer ethics. The study also indicated that the impact of individuals' extrinsic religiosity on consumer ethics might be impacted by their level of intrinsic religiosity.

Third, this study extends previous studies by segmenting consumers based on their religiosity and explores the difference between each segment. This study indicated that the religious consumers segment is more aware of unethical behaviours, thus behaving more ethically. Religious beliefs may play a role in filtering or deterring their intention to behave unethically. The results may indicate that religious principles are being upheld by a segment 
of the population, and that these principles guide their reasoning. Consequently, these principles encourage them to be responsible individuals. The less religious segment appears to be more accepting of all of those unethical behaviours. Interestingly, religious beliefs may have less impact on their intention to do recycling and doing good deeds. One explanation is that religious consumers tend to be very selective on their choice of positive contributions (e.g., donating money only to their denomination or helping only fellow believers) (Regnerus et al. 1998). This study also indicated that religiosity may discourage religious consumers from engaging in unethical behaviour but may not encourage them toward certain ethical behaviours, such as recycling and doing good deeds. It can be concluded that religiosity will have more impact on avoiding unethical behaviour than on doing good deeds. Hence, there are some implications for religious leaders, social marketers and public policy makers. For the religious leaders, the importance of protecting the environment and supporting social issues, either through volunteering or donating needs to be clearly embedded in their religious teaching. Special seminars or workshop needs to be regularly held at various places of worship (e.g., church, mosque) to effectively reach religious consumers. In addition, to effectively target religious consumers, social marketer or public policy makers can create a specific social campaign which contains a message strongly ties to their religious values. For example, a campaign for recycling targeted to a Christian community may use verses from the bible on caring the environment. Consequently, these consumers can see the benefit of caring the environment as part of their faith.

Moreover, this study indicated that high intrinsic religious consumers may exhibit high extrinsic religiosity, indicated by the high positive correlation between the two. A previous study (i.e., Arli and Tjiptono, 2014) test consumers’ intrinsic and extrinsic religiosity separately. The authors may have assumed that consumers cannot be high on both intrinsic religiosity and extrinsic religiosity. When consumers have high intrinsic religiosity, 
they are more likely to be low on their extrinsic religiosity. Nonetheless, the results of this study show that consumers with high intrinsic religiosity may expect the benefits of being a religious person (e.g., meeting friends at church). Intrinsic religiosity is highly correlated with extrinsic religiosity. Hence, consumers with high intrinsic religious may demonstrate a high level of extrinsic religiosity. Future research investigating consumers’ religiosity should investigate both their level of intrinsic and extrinsic religiosity instead of looking at this two constructs separately (e.g., Arli and Tjiptono 2014; Flurry and Swimberghe 2015). However, it is important to note that extrinsic religiosity alone (without having high intrinsic religiosity) may indicate that these consumers are less religious and less likely to be ethical, as indicated in our study. In summary, both approaches tested in this study clearly indicated the importance of including consumers' religiosity when investigating consumer ethics, even if not all relevant behaviours (i.e., recycling and doing good works) are affected by it. Religiosity still matters, and it is one of the key indicators to explore why consumers behave ethically. When we return to the question of whether ethics needs religion, based on this sample, the answer is partly yes, but it depends on which behaviour is being studied.

\section{Limitations and Future Research}

This study suffers from several limitations. First, the subjects were drawn from one city in Australia, which limits the generalizability of this study. Future research may explore other cultures or nations to increase the generalizability of the results. Second, this study did not separate and compare differences between religions (e.g., Muslims, Christians) or denominations (e.g., Baptist, Evangelical) and the study may include individuals with no religion. Each religion or denomination may have different teachings and beliefs in regards to ethical decision making. Hence, future research should investigate differences between various religions and also compare individuals who claim themselves to have a religion and 
those who claim to have no religion. Finally, this study only tested consumers' religiosity (i.e., intrinsic and extrinsic religiosity). Future studies may wish to explore and contrast the impact of consumers' religiosity versus consumer ethical ideologies (i.e., idealism and relativism). Such a study may investigate which construct plays a bigger role in impacting consumers' ethical beliefs and behaviours.

\section{References}


Albaum, G., and Peterson, R. A. (2006). Ethical Attitudes of Future Business Leaders Do They Vary by Gender and Religiosity?. Business and Society,45(3), 300-321.

Al-Khatib, J. A., Dobie, K., and Vitell, S. J. (1995). Consumer ethics in developing countries: An empirical investigation. Journal of Euro Marketing 4(2), 87-105.

Al-Khatib, J. A., Robertson, C., Al-Habib, M., and Scott J. Vitell, S. J. (2002). Ethical beliefs and orientations in the Middle East: Are Arab consumers alike? Unpublished working paper.

Al-Khatib, J. A., Stanton, A. D., and Rawwas, M. Y. A. (2005). Ethical segmentation of consumers in developing countries: A comparative analysis. International Marketing Review 22(2), 225-246

Al-Khatib, J., Vitell, S. J., and Rawwas, M. Y. A. (1997). Consumer ethics: A cross-cultural investigation. European Journal of Marketing 31(11/12), 750-767.

Allport, G. W., and Ross, J. M. (1967). Personal religious orientation and prejudice. Journal of Personality and Social Psychology, 5, 447-457.

Andaya, B. (2010). Between empires and emporia: The economics of christianization in early modern southeast Asia. Journal of the Economic and Social History of the Orient, 53, 357392.

Ang, S. H., Cheng, P. S., Lim, A. C., and Tambyat, S. K. (2001). Spot the difference: Consumer responses towards counterfeit. Journal of Consumer Marketing 18(3), 219-235.

Arli, D., and Tjiptono, F. (2014). The end of religion? Examining the role of religiousness, materialism, and long-term orientation on consumer ethics in Indonesia. Journal of Business Ethics, 123(3), 385-400

Arli, D., Cherrier, H., and Tjiptono, F. (2016). God blesses those who wear Prada: exploring the impact of religiousness on attitudes toward luxury among the youth of Indonesia. Marketing Intelligence \& Planning, 34(1). 61-79.

Arli, D., Tjiptono, F., and Winit, W. (2015). Consumer ethics among young consumers in developing countries: a cross national study. Social Responsibility Journal, 11(3), 449-466.

Australian Bureau of Statistic (2011). Reflecting a Nation: Stories from the 2011 Census, 2012-2013. Source:

http://www.abs.gov.au/ausstats/abs@.nsf/Lookup/2071.0main+features902012-2013.

Australian Bureau of Statistic (2016). Population clock. Source: http://www.abs.gov.au/ausstats/abs@.nsf/0/1647509ef7e25faaca2568a900154b63?opendocu ment.

Bagozzi, R. P., and Yi, Y. (2012). Specification, evaluation, and interpretation of structural equation models. Journal of the academy of marketing science,40(1), 8-34. 
Bateman, C. R., and Valentine, S. R. (2010). Investigating the effects of gender on consumers' moral philosophies and ethical intentions. Journal of Business Ethics, 95(3), 393414.

Chan, A., Wong, S., and Paul Leung, P. (1998, August). Ethical beliefs of Chinese consumers in Hong Kong. Journal of Business Ethics, 17, 1163-1170.

Chowdhury, R. M., and Fernando, M. (2013). The role of spiritual well-being and materialism in determining consumers' ethical beliefs: An empirical study with Australian consumers. Journal of Business Ethics, 113(1), 61-79.

Clark, J. W. and Dawson, E. L. (1996). Personal Religiousness and Ethical Judgments: An Empirical Analysis. Journal of Business Ethics, 15, 359-372.

Cornwell, B., Chi Cui, C., Mitchell, V., Schlegelmilch, B., Dzulkiflee, A., \& Chan, J. (2005). A cross-cultural study of the role of religion in consumers' ethical positions. International Marketing Review, 22(5), 531-546.

Culiberg, B. (2015). The Role of Moral Philosophies and Value Orientations in Consumer Ethics: a Post-Transitional European Country Perspective. Journal of Consumer Policy, 38(3), 211-228.

Dietrich, T., Rundle-Thiele, S., Leo, C., and Connor, J. (2015). One Size (Never) Fits All: Segment Differences Observed Following a School-Based Alcohol Social Marketing Program. Journal of School Health, 85(4), 251-259.

Donahue, M. J. (1985). Intrinsic and extrinsic religiousness: Review and metaanalysis. Journal of Personality and Social Psychology, 48(2), 400.

Donovan, R. J., Egger, G., and Francas, M. (1999). TARPARE: a method for selecting target audiences for public health interventions. Australian and New Zealand Journal of Public Health, 23(3), 280-284.

Erffmeyer, R., Keillor, B., and Thorne LeClair, D. L. (1999). An empirical investigation of Japanese consumer ethics. Journal of Business Ethics, 18, 35-50.

Flurry, L. A., and Swimberghe, K. (2016). Consumer Ethics of Adolescents. Journal of Marketing Theory and Practice, 24(1), 91-108.

Fornell, C., and Larcker, D. F. (1981). Structural equation models with unobservable variables and measurement error: Algebra and statistics.Journal of marketing research, 382388.

Gerbing, D. W. and Anderson, J.C. (1988). Structural equation modeling in practice: A review and recommended two-step approach. Psychological bulletin, 103(3), 411. 
Huffman, T. E. (1988). In the World but not of the World: Religious, Alienation, and Philosophy of Human nature among Bible college and Liberal Arts College Students', dissertation, (Iowa State University, Ames, Iowa).

Hunt, S. D., and Vitell, S. J. (1993). The general theory of marketing ethics: A retrospective and revision. In N. C. Smith and J. A Quelch (eds.), Ethics in marketing (pp. 775-784), Irwin, Homewood, IL.

Jöreskog, K. G., and Sörbom, D. (1993). LISREL 8: Structural equation modeling with the SIMPLIS command language. Scientific Software International.

Kennedy, E. J., and Lawton, L. (1998). Religiousness and business ethics. Journal of Business Ethics, 17(2), 163-175.

Lu, L. C., Chang, H. H., and Chang, A. (2015). Consumer personality and green buying intention: The mediate role of consumer ethical beliefs. Journal of Business Ethics, 127(1), 205-219.

McDaniel, S. W., and Burnett, J. J. (1990). Consumer religiosity and retail store evaluative criteria. Journal of the Academy of Marketing Science, 18(2), 101-112.

McNichols, C.W., and Zimmerer, T.W. (1985). Situational Ethics: An Empirical Study of Differentiators of Student Attitudes. Journal of Business Ethics 4(3), 174-180.

Muncy, J. A., and Eastman, J. K. (1998). Materialism and consumer ethics: An exploratory study. Journal of Business Ethics, 171(1), 137-145.

Muncy, J. A., and Vitell, S. J. (1992). Consumer ethics: An empirical investigation of the ethical beliefs of the final consumer. Journal of Business Research, 24(1), 297-312.

Norusis, M. (1994), SPSS Professional Statistics 6.1, SPSS Inc., Chicago, IL.

Patwardhan, A. M., Keith, M. E., and Vitell, S. J. (2012). Religiosity, attitude toward business, and ethical beliefs: Hispanic consumers in the United States. Journal of Business Ethics, 110(1), 61-70.

Pew Research Center (2015). The Future of World Religions: Population Growth Projections, 2010-2050. Source: http://www.pewforum.org/2015/04/02/religious-projections-2010-2050/.

Polonsky, M. J., Brito, P. Q., Pinto, P., and Higgs-Kleyn, N. (2001, May). Consumer ethics in the European Union: A comparison of northern and southern views. Journal of Business Ethics, 31, 117-130.

Punj, G., and Stewart, D. W. (1983). Cluster analysis in marketing research: Review and suggestions for application. Journal of Marketing Research, 134-148.

Rallapalli, K. C., Vitell, S. J., Wiebe, F. A., and Barnes, J. H. (1994). Consumer ethical beliefs and personality traits: An exploratory analysis. Journal of Business Ethics 13(7), 487495. 
Rawwas, M. Y. A. (1996). Consumer ethics: An empirical investigation of the ethical beliefs of Austrian consumers. Journal of Business Ethics, 15, 1009-1019.

Rawwas, M. Y. A. (2001). Culture, personality and morality: A typology of international consumers’ ethical beliefs. International Marketing Review, 18(2), 188-209.

Rawwas, M. Y. A., Patzer, G., and Klassen, M. (1995). Consumer ethics in cross cultural settings. European Journal of Marketing 29(7), 62-78.

Rawwas, M. Y. A., Patzer, G. and Vitell, S. J. (1998). A cross cultural investigation of the ethical values of consumers: The potential effect of war and civil disruption. Journal of Business Ethics, 17(3), 435-448.

Rawwas, M. Y. A., and Singhapakdi, A. (1998). Do consumers' ethical beliefs vary with age: A substantiation of Kohlberg's Typology in marketing. Journal of Marketing Theory and Practice, 6, 26-38.

Rawwas, M. Y. A., Strutton, D., and Johnson, L. W. (1996). An exploratory investigation of the ethical values of American and Australian consumers. Journal of Direct Marketing, 10, 52-63.

Rawwas, M. Y. A., Vitell, S. J. and Al-Khatib, J.A. (1994). Consumer ethics: The possible effects of terrorism and civil unrest on the ethical values of consumers. Journal of Business Ethics 13(3), 223-231.

Razu, I. (2006). “'Let them come” — “let them work”: Receiving/ using children in a globalized world. Studies in World Christianity, 12(3), 249-265.

Regnerus, M. D., Smith, C., and Sikkink, D. (1998). Who gives to the poor? The influence of religious tradition and political location on the personal generosity of Americans toward the poor. Journal for the Scientific Study of Religion, 481-493.

Sanchez, R. (2016). Why the onslaught of religious freedom laws. Source: http://edition.cnn.com/2016/04/06/us/religious-freedom-laws-why-now/.

Schneider, H., Krieger, J., and Bayraktar, A. (2011). The impact of intrinsic religiosity on consumers' ethical beliefs: Does it depend on the type of religion? A comparison of Christian and Moslem consumers in Germany and Turkey. Journal of Business Ethics, 102(2), 319332.

Strutton, D., Scott, J., Vitell, S. J. and Pelton, L. E. (1994). How consumers may justify inappropriate behavior in market settings: An application on the techniques of neutralization. Journal of Business Research, 30, 253-260

Swaidan, Z., Vitell, S. J., Rose, G. M., and Gilbert, F. W. (2006). Consumer ethics: The role of acculturation in US immigrant populations. Journal of Business Ethics, 64(1), 1-16. 
Van Kenhove, P., Vermeir, I. and Verniers, S. (2001). An empirical investigation of the relationships between ethical beliefs, ethical ideology, political preference and need for closure. Journal of Business Ethics, 32, 347-361

Vitell, S. J. and Muncy, J. (1992). Consumer ethics: An empirical investigation of factors influencing ethical judgments of the final consumer. Journal of Business Ethics, 11, 585-597.

Vitell, S. J., and Paolillo, J. G. (2003). Consumer ethics: The role of religiosity. Journal of Business Ethics, 46(2), 151-162.

Vitell, S. J., Paolillo, J. G., and Singh, J. J. (2005). Religiosity and consumer ethics. Journal of Business Ethics, 57(2), 175-181.

Vitell, S. J., Paolillo, J. G., and Singh, J. J. (2006). The role of money and religiosity in determining consumers’ ethical beliefs. Journal of Business Ethics, 64(2), 117-124.

Vitell, S. J., Singh, J. J., and Paolillo, J. G. (2007). Consumers' ethical beliefs: The roles of money, religiosity and attitude toward business. Journal of Business Ethics, 73(4), 369-379.

Vitell, S. J., King, R. A., Howie, K., Toti, J. F., Albert, L., Hidalgo, E. R., and Yacout, O. (2015). Spirituality, Moral Identity, and Consumer Ethics: A Multi-cultural Study. Journal of Business Ethics, 1-14.

Zhao, B., and Xu, S. (2013). Does consumer unethical behavior relate to birthplace? Evidence from China. Journal of Business Ethics, 113(3), 475-488. 
Figure 1. Conceptual Framework

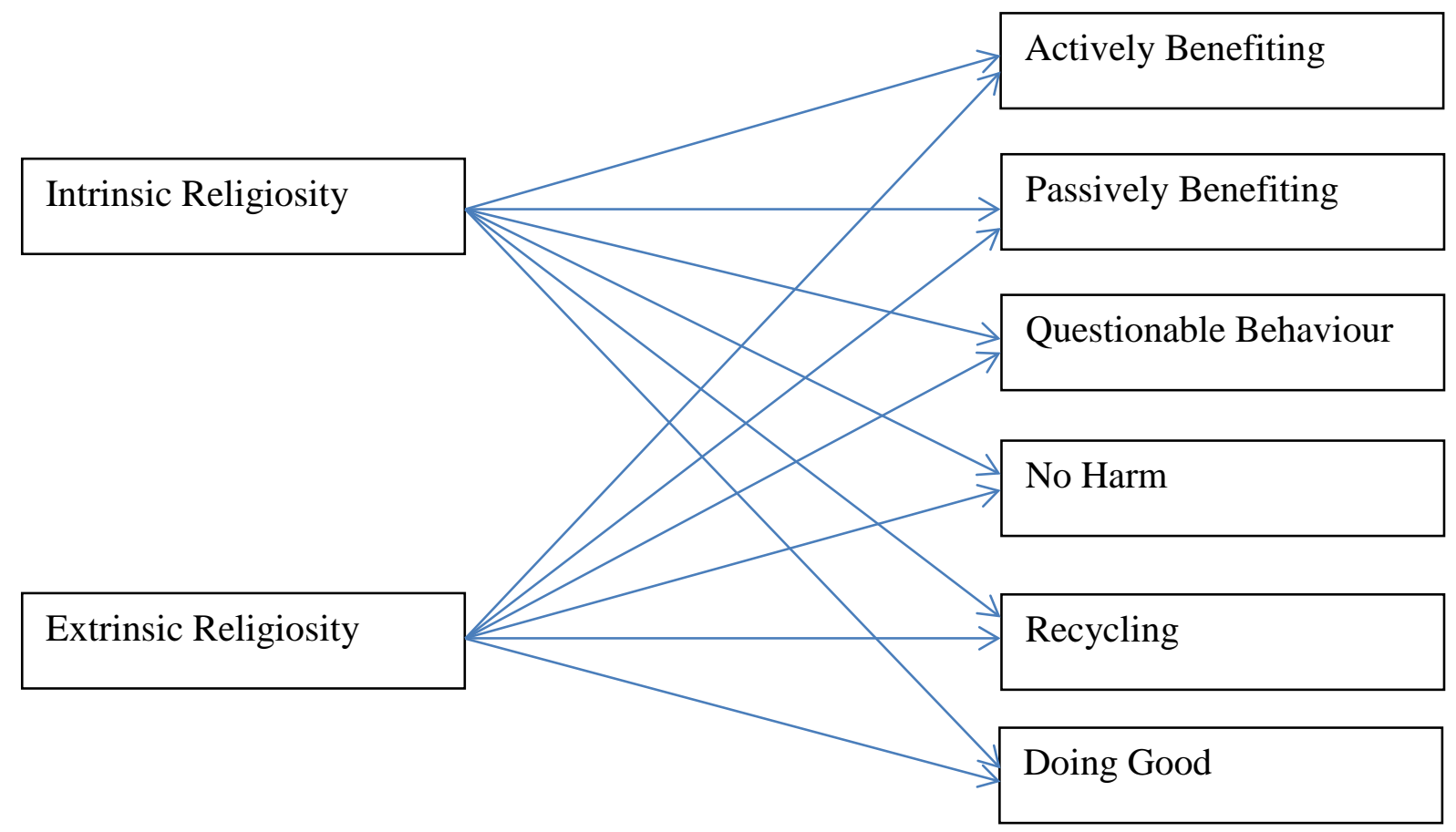




\section{Appendix}

Table 1. Summary of empirical studies

\begin{tabular}{|c|c|c|c|}
\hline $\begin{array}{l}\text { Author(s) (based on the } \\
\text { year of study) }\end{array}$ & Context of the study & Variables & Results \\
\hline Vitell and Paolillo 2003 & USA (Students, $\mathrm{n}=353$ ) & $\begin{array}{l}\text { Dependent Variables: Consumer } \\
\text { ethics (Active, Passive, } \\
\text { Questionable, No Harm) } \\
\text { Independent Variable: Religiosity } \\
\text { (Wilkes et al. 1986) }\end{array}$ & Religiosity had no effect on all consumer ethics scales \\
\hline $\begin{array}{l}\text { Vitell, Paolillo and Singh } \\
2005\end{array}$ & USA (Students, $\mathrm{n}=114$ ) & $\begin{array}{l}\text { Dependent Variables: Consumer } \\
\text { ethics (Active, Passive, } \\
\text { Questionable, No Harm) } \\
\text { Independent Variables: Intrinsic, } \\
\text { Extrinsic (Allport and Ross 1967) }\end{array}$ & $\begin{array}{l}\text { Intrinsic religiosity had a negative effect on Active, Passive, } \\
\text { Questionable (no effect on No Harm) } \\
\text { Extrinsic religiosity had no effect on all consumer ethics scales }\end{array}$ \\
\hline $\begin{array}{l}\text { Vitell, Paolillo and Singh } \\
2006\end{array}$ & USA (Adults, n=127) & $\begin{array}{l}\text { Dependent Variables: Consumer } \\
\text { ethics (Active, Passive, } \\
\text { Questionable, No Harm) } \\
\text { Independent Variables: } \\
\text { Intrinsic(Allport and Ross 1967) }\end{array}$ & $\begin{array}{l}\text { Intrinsic religiosity had a negative effect on Active, Passive, } \\
\text { Questionable (no effect on No Harm) }\end{array}$ \\
\hline $\begin{array}{l}\text { Vitell, Singh and Paolillo } \\
2007\end{array}$ & USA (Adults, n=127) & $\begin{array}{l}\text { Dependent Variables: Consumer } \\
\text { ethics (Active, Passive, } \\
\text { Questionable, No Harm) } \\
\text { Independent Variables: Intrinsic, } \\
\text { Extrinsic (Allport and Ross 1967) }\end{array}$ & $\begin{array}{l}\text { Intrinsic religiosity had a negative effect on Active, Passive, } \\
\text { Questionable (no effect on No Harm) } \\
\text { Extrinsic religiosity had no effect on all consumer ethics scales }\end{array}$ \\
\hline $\begin{array}{l}\text { Scheinder, Krieger and } \\
\text { Bayraktar } 2011\end{array}$ & $\begin{array}{l}\text { Germany (Students, n=240); } \\
\text { Turkey (Students, } n=231 \text { ) }\end{array}$ & $\begin{array}{l}\text { Dependent Variables: Consumer } \\
\text { ethics (Active, Passive, No Harm) } \\
\text { Independent Variables: Intrinsic } \\
\text { (Allport and Ross 1967) }\end{array}$ & $\begin{array}{l}\text { Germany: Intrinsic religiosity had no effect on all consumer } \\
\text { ethics scales. } \\
\text { Turkey: Intrinsic religiosity had a negative effect on Active, } \\
\text { Passive, No Harm). }\end{array}$ \\
\hline $\begin{array}{l}\text { Patwardhan, Keith and Vitell } \\
2012\end{array}$ & $\begin{array}{l}\text { US-Mexico Border } \\
\text { (Students, } \mathrm{n}=187 \text { ) }\end{array}$ & $\begin{array}{l}\text { Dependent Variables: Consumer } \\
\text { ethics (Active, Passive, } \\
\text { Questionable, No Harm, Doing } \\
\text { Good) } \\
\text { Independent Variables: Intrinsic } \\
\text { and Extrinsic (Allport and Ross } \\
\text { 1967). }\end{array}$ & $\begin{array}{l}\text { Intrinsic religiosity had a negative effect on Active, Passive, } \\
\text { Questionable (no effect on Good) } \\
\text { Extrinsic religiosity had an positive effect on Active (no effect } \\
\text { on Passive, Questionable, No Harm and Doing Good) }\end{array}$ \\
\hline
\end{tabular}


Table 1. Summary of empirical studies (2)

\begin{tabular}{|c|c|c|c|}
\hline Author(s) & Context of the study & Variables & Results \\
\hline Lu and Lu 2010 & $\begin{array}{l}\text { Indonesia (Adults, factory } \\
\text { workers, } n=280 \text { ) }\end{array}$ & $\begin{array}{l}\text { Dependent Variables: Consumer } \\
\text { ethics (Active, Passive, } \\
\text { Questionable, No Harm) } \\
\text { Independent Variables: Religion } \\
\text { (i.e., Islam and others) }\end{array}$ & $\begin{array}{l}\text { No significant differences between Islam and other religions on } \\
\text { their ethical beliefs }\end{array}$ \\
\hline Arli and Tjiptono 2014 & Indonesia (Students, n=397) & $\begin{array}{l}\text { Dependent Variables: Consumer } \\
\text { ethics (Actively benefiting, } \\
\text { Passively benefiting, Questionable, } \\
\text { No Harm, Downloading, Recycling, } \\
\text { Doing Good). } \\
\text { Independent Variables: Intrinsic, } \\
\text { Extrinsic Personal, Extrinsic Social } \\
\text { (Allport and Ross 1967) }\end{array}$ & $\begin{array}{l}\text { Intrinsic religiosity had a negative effect on Active, Passive, } \\
\text { Questionable and Doing Good (no effect on No Harm and } \\
\text { Downloading and Recycling). } \\
\text { Extrinsic personal religiosity had no effect on all consumer } \\
\text { ethics scales. } \\
\text { Extrinsic social religiosity had a positive effect on Active, } \\
\text { Passive, Questionable, No Harm, Downloading and Doing } \\
\text { Good (no effect on Recycling). }\end{array}$ \\
\hline Vitell et al. 2015 & USA $(n=198)$ & $\begin{array}{l}\text { Dependent Variables: Consumer } \\
\text { ethics (Actively benefiting, } \\
\text { Passively benefiting, Doing Good) } \\
\text { Independent variable: Spirituality } \\
\text { (Ryan and Fiorito 2013) }\end{array}$ & $\begin{array}{l}\text { Spirituality had a negative effect on Actively benefiting, } \\
\text { Passively benefiting (no effect on doing good). }\end{array}$ \\
\hline Flurry and Swimberghe, 2015 & USA (Adolescents, n=500) & $\begin{array}{l}\text { Dependent Variables: Consumer } \\
\text { ethics (Actively benefiting, } \\
\text { Passively benefiting, Questionable, } \\
\text { Doing Good) } \\
\text { Independent variable: Parent's } \\
\text { intrinsic religiosity, parent's } \\
\text { extrinsic religiosity (Allport and } \\
\text { Ross 1967). }\end{array}$ & $\begin{array}{l}\text { Parents' intrinsic religiosity had a negative effect on passively } \\
\text { benefiting, questionable (no effect on actively benefiting and } \\
\text { doing good). } \\
\text { Parents' extrinsic religiosity had no effect on all consumer } \\
\text { ethics scales. }\end{array}$ \\
\hline
\end{tabular}


Table 2. Demographic Profile $(n=517)$

\begin{tabular}{|c|c|c|}
\hline Demographic & Frequencies & Percentage \\
\hline \multicolumn{3}{|l|}{ Gender } \\
\hline Male & 258 & $49.9 \%$ \\
\hline Female & 259 & $50.1 \%$ \\
\hline \multicolumn{3}{|l|}{ Age } \\
\hline 18-24 years & 269 & $52 \%$ \\
\hline 25-34 years & 85 & $16.4 \%$ \\
\hline 35-44 years & 30 & $5.8 \%$ \\
\hline 45-54 years & 82 & $15.9 \%$ \\
\hline 55-64 years & 51 & $9.9 \%$ \\
\hline \multicolumn{3}{|l|}{ Marital Status } \\
\hline Single & 277 & $53.9 \%$ \\
\hline Married & 138 & $26.8 \%$ \\
\hline Divorced & 33 & $6.4 \%$ \\
\hline Widowed & 10 & $1.9 \%$ \\
\hline Other & 56 & $10.9 \%$ \\
\hline \multicolumn{3}{|l|}{ Income } \\
\hline Less than $\$ 20,000$ & 186 & $36.6 \%$ \\
\hline$\$ 21,000-\$ 40,000$ & 104 & $20.5 \%$ \\
\hline$\$ 41,000-\$ 60,000$ & 100 & $19.7 \%$ \\
\hline$\$ 61,000-\$ 81,000$ & 49 & $9.6 \%$ \\
\hline$\$ 81,000-\$ 100,000$ & 31 & $6.1 \%$ \\
\hline Above $\$ 100,000$ & 38 & $7.5 \%$ \\
\hline
\end{tabular}


Table 3. Confirmatory Factor Analysis

\begin{tabular}{|c|c|c|c|c|c|}
\hline \multirow[t]{2}{*}{ Factor } & \multirow[t]{2}{*}{ Item } & \multicolumn{2}{|c|}{ Convergent Validity } & \multicolumn{2}{|c|}{ Reliability } \\
\hline & & Factor Loading & Loading Average & AVE & CR \\
\hline \multirow{3}{*}{ Intrinsic Religiosity } & $\begin{array}{l}\text { It is important to me to spend time in private } \\
\text { thought and prayer. }\end{array}$ & 0.83 & & & \\
\hline & $\begin{array}{l}\text { I have often had a strong sense of God’s } \\
\text { presence. }\end{array}$ & 0.88 & & & \\
\hline & My whole approach to life is based on religion. & 0.83 & & & \\
\hline \multirow[t]{4}{*}{ Extrinsic Religiosity } & $\begin{array}{l}\text { What religion offers me most is comfort in } \\
\text { times of trouble and sorrow. }\end{array}$ & 0.89 & 0.75 & 0.58 & 0.72 \\
\hline & Prayer is for peace and happiness. & 0.75 & & & \\
\hline & $\begin{array}{l}\text { I pray mainly to gain relief and protection. } \\
\text { I go to a religious service because I eniov }\end{array}$ & 0.84 & & & \\
\hline & seeing people I know there. & 0.67 & & & \\
\hline
\end{tabular}


Table 3 (Cont). Confirmatory Factor Analysis

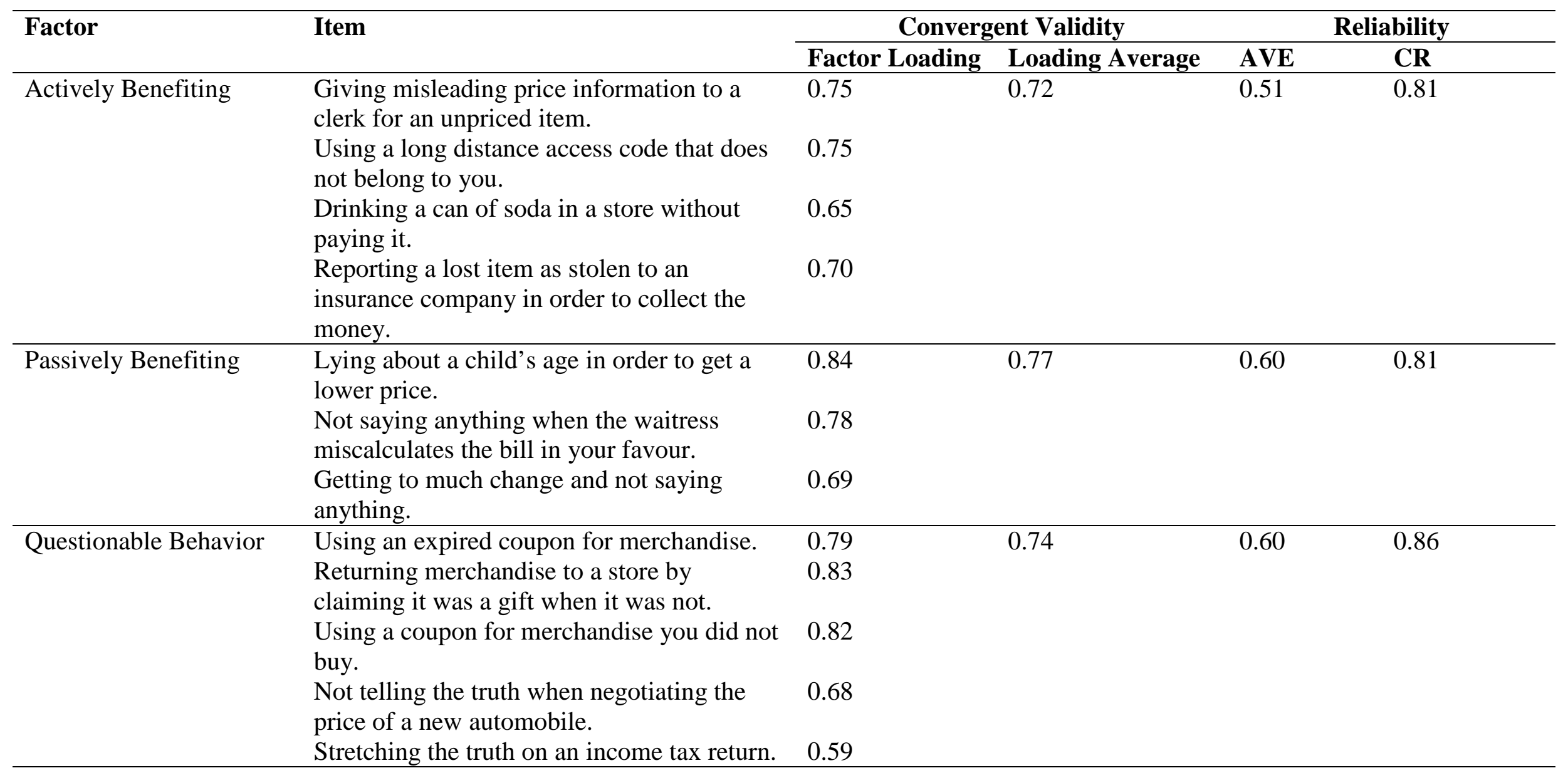


Table 3 (Cont). Confirmatory Factor Analysis

\begin{tabular}{|c|c|c|c|c|c|}
\hline \multirow[t]{2}{*}{ Factor } & \multirow[t]{2}{*}{ Item } & \multicolumn{2}{|c|}{ Convergent Validity } & \multicolumn{2}{|c|}{ Reliability } \\
\hline & & Factor Loading & Loading Average & AVE & CR \\
\hline No Harm & $\begin{array}{l}\text { Using a computer software or games that you } \\
\text { did not buy. }\end{array}$ & 0.92 & & & \\
\hline \multirow[t]{3}{*}{ Recycling } & $\begin{array}{l}\text { Buying products labelled as “environmentally } \\
\text { friendly” even if they don’t work as well as } \\
\text { competing products. }\end{array}$ & 0.79 & 0.82 & 0.66 & 0.86 \\
\hline & $\begin{array}{l}\text { Purchasing something made of recycled } \\
\text { materials even though it is more expensive. }\end{array}$ & 0.86 & & & \\
\hline & $\begin{array}{l}\text { Buying only from companies that have a strong } \\
\text { record of protecting the environment. }\end{array}$ & 0.79 & & & \\
\hline \multirow[t]{2}{*}{ Doing Good } & $\begin{array}{l}\text { Returning to the store and paying for an item } \\
\text { that the cashier mistakenly did not charge you } \\
\text { for. }\end{array}$ & 0.87 & 0.73 & 0.55 & 0.85 \\
\hline & $\begin{array}{l}\text { Not purchasing products from companies that } \\
\text { you believe don't treat their employees fairly. }\end{array}$ & 0.61 & & & \\
\hline
\end{tabular}


Table 4. Discriminant Validity - All Construct

\begin{tabular}{|c|c|c|c|c|c|c|c|c|}
\hline & 1 & 2 & 3 & 4 & 5 & 6 & 7 & 8 \\
\hline 1. Intrinsic Religiosity & 0.70 & 0.594 & 0.039 & 0.120 & 0.113 & 0.080 & 0.005 & 0.002 \\
\hline 2. Extrinsic Personal & $0.771 * *$ & 0.58 & 0.005 & 0.062 & 0.070 & 0.064 & 0.012 & 0.005 \\
\hline 3. Actively Benefiting & $0.197 * *$ & 0.072 & 0.51 & 0.316 & 0.260 & 0.166 & 0.002 & 0.060 \\
\hline 4. Passively Benefiting & $0.346 * *$ & $0.249 * *$ & $0.562 * *$ & 0.60 & 0.466 & 0.297 & 0.002 & 0.023 \\
\hline 5. Questionable Behavior & $0.336 * *$ & $0.264 * *$ & $0.510 * *$ & $0.683 * *$ & 0.60 & 0.382 & 0.011 & 0.009 \\
\hline 6. No Harm & $0.283 * *$ & $0.252 * *$ & $0.408 * *$ & $0.545 * *$ & $0.618 * *$ & 0.79 & 0.023 & 0.000 \\
\hline 7. Recycling & 0.069 & $0.111^{*}$ & -0.047 & 0.040 & $0.106 *$ & $0.150 * *$ & 0.66 & 0.256 \\
\hline 8. Doing Good & 0.043 & 0.068 & -0.245 & $-0.153^{* *}$ & -0.093 & 0.004 & $0.506^{* *}$ & 0.55 \\
\hline Mean & 2.51 & 2.43 & 3.98 & 3.42 & 3.32 & 2.85 & 2.44 & 2.14 \\
\hline Std Dev & 1.15 & 0.97 & 0.76 & 0.97 & 0.87 & 0.98 & 0.74 & 0.83 \\
\hline
\end{tabular}

Notes: Values below the diagonal are bivariate correlations between the constructs, bold diagonal elements represents the Average Variance Extracted (AVEs) for the relevant construct; Values above the diagonal represent squared correlations; Values below the diagonal represent correlations 
Table 5. Structural Equation Model Results

\begin{tabular}{llll}
\hline Hypothesis & Structural Relationship & Standardized Coefficient & Hypothesis Results \\
\hline H1a & Intrinsic Religiosity $\rightarrow$ Actively Benefiting & Supported \\
H1b & Intrinsic Religiosity $\rightarrow$ Passively Benefiting & $\mathbf{6 . 7 4 9} * *$ & Supported \\
H1c & Intrinsic Religiosity $\rightarrow$ Questionable Behavior & $\mathbf{8 . 4 6 9}^{* *}$ & Supported \\
H1d & Intrinsic Religiosity $\rightarrow$ No Harm & $\mathbf{8 . 1 4 3} * *$ & Supported \\
H1e & Intrinsic Religiosity $\rightarrow$ Recycling & $\mathbf{6 . 4 7 7 * *}$ & Not supported \\
H1f & Intrinsic Religiosity $\rightarrow$ Doing Good & 0.919 & Supported \\
\hline H2a & Extrinsic Religiosity $\rightarrow$ Actively Benefiting & $\mathbf{- 2 . 1 4 2 *}$ & Supported \\
H2b & Extrinsic Religiosity $\rightarrow$ Passively Benefiting & $\mathbf{- 6 . 5 4 2 * *}$ & Supported \\
H2c & Extrinsic Religiosity $\rightarrow$ Questionable Behavior & $\mathbf{- 8 . 1 0 7 * *}$ & Supported \\
H2d & Extrinsic Religiosity $\rightarrow$ No Harm & $\mathbf{- 7 . 7 8 8 * *}$ & Supported \\
H2e & Extrinsic Religiosity $\rightarrow$ Recycling & $\mathbf{- 6 . 1 7 8 * *}$ & Not supported \\
H2f & Extrinsic Religiosity $\rightarrow$ Doing Good & -0.841 & Supported \\
\hline Notes: $* * p<0.01 ; * p<0.05 ; X^{2}(442 \mathrm{df})=936.769, p=0.00 ;$ NFI $=0.92 ;$ TLI $=0.95 ;$ CFI $=0.96 . ;$ IFI=0.96; RMSEA=0.047
\end{tabular}


Table 6. Independent t-test

\begin{tabular}{|c|c|c|c|}
\hline Consumer Ethics & Mean (SD) & Significant & Hypothesis Results \\
\hline \multicolumn{4}{|l|}{ Actively Benefiting } \\
\hline Less-religious Segment & $3.88(0.77)$ & 0.006* & (H3a ) Supported \\
\hline Religious Segment & $4.06(0.74)$ & & \\
\hline \multicolumn{4}{|l|}{ Passively Benefiting } \\
\hline Less-religious Segment & $3.14(0.99)$ & $0.000 * *$ & (H3b) Supported \\
\hline Religious Segment & $3.66(0.89)$ & & \\
\hline \multicolumn{4}{|l|}{ Questionable Behavior } \\
\hline Less-religious Segment & $3.04(0.86)$ & $0.000 * *$ & (H3c) Supported \\
\hline Religious Segment & $3.54(0.81$ & & \\
\hline \multicolumn{4}{|l|}{ No-Harm } \\
\hline Less-religious Segment & $2.58(0.97)$ & $0.000 * *$ & (H3d) Supported \\
\hline Religious Segment & $3.07(0.94)$ & & \\
\hline \multicolumn{4}{|l|}{ Recycling } \\
\hline Less-religious Segment & $2.37(0.78)$ & 0.054 & (H3e) Not supported \\
\hline Religious Segment & $2.50(0.71)$ & & \\
\hline \multicolumn{4}{|l|}{ Doing Good } \\
\hline Less-religious Segment & $2.09(0.82)$ & 0.193 & (H3f) Not supported \\
\hline Religious Segment & $2.18(0.84)$ & & \\
\hline
\end{tabular}


